Revue

Revue de l'histoire des religions

de Ihistoire des religions

$1 \mid 2006$

Varia

\title{
The origins of Christian veneration of body-parts
}

Les origines de la vénération chrétienne de fragments humains

John Wortley

CpenEdition

Journals

Electronic version

URL: https://journals.openedition.org/rhr/4620

DOI: $10.4000 /$ rhr.4620

ISSN: $2105-2573$

Publisher

Armand Colin

Printed version

Date of publication: 1 March 2006

Number of pages: 5-28

ISBN: 2200-92103-9

ISSN: 0035-1423

Electronic reference

John Wortley, "The origins of Christian veneration of body-parts", Revue de l'histoire des religions [Online], 1 | 2006, Online since 18 January 2010, connection on 21 September 2021. URL: http:// journals.openedition.org/rhr/4620 ; DOI: https://doi.org/10.4000/rhr.4620

Tous droits réservés 


\section{The origins of Christian veneration of body-parts}

Why did Christians chose to retain human corpses unburied and to dismember them, when most other people felt obliged to dispose of the dead, usually by burial or incineration? Three possible reasons are discussed. First, the marked emphasis on physical contact in all the biblical cases of healing (a buried body cannot be touched). Secondly, incinerated remains could be legally retained unburied and may have provided the earliest objects of Christian relic devotion. Thirdly, the Egyptian Christians, (we learn from Athanasius) adopted the long-standing pagan practice of embalming the corpses of martyrs and exposing them in private houses, ready prey for unscrupulous men who, realizing the popularity of such relics, were not slow to appreciate the advantages of trafficking in them.

\section{Les origines de la vénération chrétienne de fragments humains}

Pourquoi les chrétiens ont-ils choisi de conserver sans les ensevelir des cadavres humains et de les démembrer, alors que la plupart des autres peuples se sont sentis obligés de se débarrasser des morts, habituellement en les ensevelissant ou en les incinérant? Trois raisons possibles sont examinées ici. D'abord, l'importance manifeste du contact physique dans tous les exemples bibliques de guérison (on ne peut pas toucher un corps enterré). Ensuite, des restes incinérés pouvaient être conservés légalement sans être enterrés et peuvent avoir fourni les plus anciens objets de la vénération chrétienne des reliques. Enfin, les chrétiens d'Égypte (nous le savons par Athanase) adoptèrent une pratique païenne de longue date, celle de l'embaumement des corps de martyrs et de leur exposition dans des maisons privées, faisant ainsi de ces derniers une proie facile pour des personnes sans scrupule qui, conscientes de la popularité de ces reliques, ne tardèrent pas à réaliser les avantages que l'on pouvait tirer de leur commerce. 
The evil that men do, lives after them, the good is oft interred with their bones. (Shakespeare, Julius Caesar, 3.2.75-76)

\section{The RELIC-HOARD OF CONSTANTINOPLE}

Between 359 and 1204 Constantinople gradually acquired an immense hoard of "holy relics" which, at least for some, constituted that city's chief claim to fame. What was it, we may well ask, that motivated Constantinople to amass that huge relic collection? Why were those relics so coveted that they were even capable (it is said) of diverting an entire crusade in pursuit of them? ${ }^{1}$ The East Romans were not of course alone in acquiring relics; they just did it on a far grander scale (given the greater resources disposable) than the rest of Christendom, much in the same way that the USA acquires the world's art-treasures today. But the question still remains: why was it done at all?

There are both immediate and remote aspects to this question. The immediate aspects concern the perceived intrinsic value of relics, a matter which has mostly been dealt with fairly thoroughly elsewhere. Briefly, holy relics were believed to diffuse a certain power [dynamis] both directly and indirectly; there was a fully-worked out theory indicating that the dynamis of the relics was conceived of much in the same way as we think of radio-activity (except of course that dynamis was entirely beneficial). Thus even the tiniest fragment of a relic was capable of discharging the same level of dynamis as the entire corpse (or object); merely the place where relics had once lain $^{2}$ or oil which had been poured over them was thought to be

1. Such is the widely accepted hypothesis of Anton Frolow, "La déviation de la 4" Croisade vers Constantinople: problème d'histoire et de doctrine", Revue de l'histoire des religions 145 (1954) 168-187, 146 (1954) 67-89 and 194-219.

2. John Chrysostom says that even after the relics of Babylas were removed from Daphnê in 362, the spot where they had lain continued to exercise healing power over those who prayed there: Discours sur Babylas \& Homelie sur Babylas ed. Margaret A. Schatkin, trans. Cécil Blanc and Bernard Gillet, Paris 1990 (Sources Chrétiennes 362) c. 126. 
capable of producing the same remarkable effects as the whole corpse for the healing of body, mind and spirit.

In a wider sense relics were a secret weapon to deploy against the foe. "The bodies of the saints are a stronger protection for our city than any adamantine and inexpugnable fortification" says John Chrysostom. "Like so many high look-out towers set all about her, they repulse the onslaughts, not only of those enemies which can be seen and heard, but also the attacks of the invisible demons, repelling every device of the devil. This they do with ease too, just as a vigorous man will turn back and frustrate the playful advances of children." 3 This and much more like it is already well known: our Christian forefathers were convinced of the efficacy of relics; and there is good reason to suppose that, like most things one truly believes in, the relics sometimes actually did what they were believed to be capable of doing.

Now relics are of various kinds. Although Constantinople undoubtedly acquired many of the so-called "secondary relics" (man-made or natural objects associated with some holy person) these can be set aside for the purposes of this paper. Nor are we here talking about saints' bodies decently and legally entombed, of which Constantinople inherited very few, ${ }^{4}$ although these are undoubtedly of capital importance. We have the extraordinary endorsement Eusebius of Caesarea of the veneration of the tombs of those who died gloriously, using the authority of Plato and Hesiod. ${ }^{5}$ There is

3. John Chrysostom, In martyres Agyptos, Patrologia Graeca 50:693. Except where stated otherwise, all translations are the writer's own work; biblical quotations are mostly from the Authorised Version of 1611 (alias "King James' Bible").

4. John Wortley, "The Byzantine component of the relic-hoard of Constantinople", Greek Roman and Byzantine Studies 40 (1999) 307-332.

5. Eusèbe de Césarée, La Préparation Evangélique livres XII-XIII, edited and translated by Edouard des Places, Sources chrétiennes 307, Paris 1983, pp.306-309 Plato is quoted saying: "And henceforth we shall honour and revere [heroes'] tombs because they became daemons. And we shall do likewise when one of those who are judged to be outstandingly good in life dies of old age or any other way." Eusebius comments: "The same applies to the death of those who love God, whom we would not be in error in calling soldiers of the true religion. Thus it is our custom to go to their tombs, to offer our prayers there, to honour their blessed souls, these practices being reasonable." 
also the passage in Apostolic Constitutions expressly relieving Christians of any Jewish doubts about the cleanliness of the graves of the holy ones. ${ }^{6}$ Devotions to and at the sites where corpses have been decently and definitively disposed of pertain to an immemorial tradition for all peoples; but such sites need not detain us now.

What is in question here is human remains which have been disinterred (temporally or permanently) or not yet laid to rest and (in many cases) remained uninterred, even on display. Given the paucity of saints known to have died at Constantinople, the greater part of that city's relic-hoard had to be of this order. Thus that hoard perforce consisted of all (or part) of what is left of a person when the fire has gone out, like costumes and fragments of costumes left behind in the green room after the actors have gone home. The question inevitably arises: given that our Christian ancestors were already involved in the ancient and near-universal tradition of devotion to (or at) the places where the mortal remains of significant persons lay tidied away, how did it come about that Christians broke with that tradition in such an extraordinary way? What made them desire actually to handle and to cherish directly the mortal remains of their deceased brethren?

\section{TRADITIONAL ATTITUDES TO THE HUMAN CORPSE}

This was certainly not a desire which came with their Judaic heritage; in Jewish law the cadaver is a source of ritual pollution, a thing to be disposed of as quickly as possible, preferably before the sun begins another circle of the earth. ${ }^{7}$ Decent and definitive burial

6. Apostolic Constitutions 6.30.3-5, denying that one is in some way defiled by contact with a corpse and therefore must perform rituals to purge the defilement. Christians need not hesitate (the writer opines) to assemble at tombs of the saints, there to celebrate the Eucharist, offering prayers, hymns and so forth.

7. "Whosoever toucheth one that is slain with a sword in the open fields, or a dead body, or a bone of a man, or a grave, shall be unclean seven days", Numbers $19^{16}$. The Law does not precisely require immediate burial (Deuteronomy $21^{23}$ refers to the corpse of an executed criminal) but this became the general practice for fear of ritual contamination. 
of the deceased was always held to be of greatest importance and an inescapable obligation on the living, not only in Israel but throughout the Near-East. Thus the ancient Greeks regarded denial of burial as something that even an enemy should not suffer. We read of many a battle where a truce is called so that each side can bury its dead before resuming the slaughter. A frequent curse in Greek heroic literature involves an enemy's corpse being left exposed as carrion for dogs or birds. ${ }^{8}$ One reason why that curse was so strong is that life was held not to have come to a natural and proper close until one's body had been buried. In a belief-system in which one passed from this life to the next, absence of burial meant that the next stage of existence could not take place until the prior phase had been completed. Thus the wraiths of the unburied could not cross the Styx. The whole issue in Antigone (the burial of Polyneices) is an indication of how seriously the obligation to bury one's relatives was, even one deemed to be an enemy of the state. In the legends of the Golden Fleece, Jason conceals the real object of the voyage with the tale that the Argonauts at going to Colchis to inter the unburied remains of Phrixus, hanging in a tree.

The Romans too insisted that human remains be tidied away, outside the city, as quickly and as decently as possible; the Emperor Julian even objected to corpses being carried through the streets for (he says) "this practice pollutes the eyes of men by its ill-omened aspect" while Theodosius the Great, himself no enemy of the relics, says that the presence of human remains violates the sanctity of the home. ${ }^{9}$ The sneer of Eunapius of Sardis (ob. post 414) probably expresses the universal disgust of the pagan world at the Christians' penchant for relics; it loses nothing in Gibbon's translation:

8. "Not only the Egyptians [...] but also the peoples of Mesopotamia dreaded above all else the thought of lying unburied". One of the most frequently employed curses found in Mesopotamian texts is: "May the earth not receive your corpses," or the equivalent", [e.g.] "And thy carcase shall be meat unto all fowls of the air, and unto the beasts of the earth, and no man shall fray them away", Deut $28^{26}$, D.R.H., "Burial in the Bible", Encyclopaedia Judaica vol. 4, Jerusalem 1971, cols. 1515-1516.

9. Codex Theodosianum. 19.17.5 \& 6. The mention of the home is of particular interest in the light of what is said below about Egyptians. 
The heads, salted and pickled, of those infamous malefactors, who for the multitude of their crimes have suffered a just and ignominious death; their bodies, still marked by the impression of the lash and the scars of those tortures which were afflicted by the sentence of the magistrate; such are the gods which the earth produces in our days; such are the martyrs, the supreme arbiters of our prayers and petitions to the Deity, whose tombs are now consecrated as the objects of the veneration of the people. ${ }^{10}$

\section{Physical Contact in thaumaturgic healings}

It begins to look as though Christianity was born into a world in which Jews, Greeks and Romans uniformly shunned and eschewed unburied human remains; why then did Christians choose to swim against this prevailing stream and embrace them? They were not taught do so by their Scriptures; some precedent would eventually appear to be found in the Hebrew scriptures ${ }^{11}$ but there is certainly no hint of a cult of the corpse in the New Testament. There is, however, something else found in the Christian Gospels (and, to a certain extent, in Acts) which might be relevant here: that is, a marked emphasis on physical contact when a healing ministry is being exercised. It seems to be nearly always the case that persons are cured when they come into bodily contact either with Jesus himself or with one of his thaumaturgic followers. Physical contact is a feature of the frequently cited Old Testament precedent for venerating the relics too: "... and when the [dead] man was let down, and touched the bones of Elisha he revived and stood up on his feet". 12

The contact on which healing depends need not however be direct contact. Take for instance the case of the "woman with an

10. From The Life of the Sophist Aedesius, tr. Edward Gibbon, The History of the Decline and Fall of the Roman Empire edited by John Bagnell Bury, London 1909, 3:219.

11. See J. Wortley, "Icons and Relics: a comparison", GRBS 43 (2002/3) $161-174$.

12. $2 / 4$ Kings $13^{20-21}$. "When this man's corpse came into contact with the bones of Elisha he rose up and lived. This would not have happened if the body of Elisha had not been holy", Apostolic Constitutions 6.30.5. 
issue of blood" (haemorrhousa) who says: "If I may but touch the hem of his garment I shall be healed" - which she does and is healed, the Lord perceiving that dynamis had gone out of him. Indeed, "they laid the sick in the streets and besought Him that they might touch but if it were the border of his garment: and as many as touched Him were made whole". ${ }^{13}$ Luke writes in Acts: "God wrought special miracles by the hands of Paul: so that from his body were brought unto the sick handkerchiefs and aprons and the diseases departed from them". ${ }^{14}$ We even hear of the sick being laid out "that at least the shadow of Peter passing by might overshadow some of them", presumably that they might be healed. ${ }^{15}$

Thus the healing dynamis of a thaumaturge could be relayed or conducted from his body in various ways; from his living body, that is, for in every single case of healing in the Gospels or Acts it is contact (direct or indirect) with a living body which is therapeutic, not with a corpse. If that were all there is, things might have been very different, but there is more. There is that one outstanding instance of a therapeutic corpse found in the Old Testament. Given that celebrated precedent, it is not difficult to imagine how, in the process of time, the buried corpse of a thaumaturge came to be credited with the powers of the living person,. This would certainly account for the Christian devotion at the martyrion where a hero of the faith lay decently buried. But maybe that was not enough; maybe the tradition of physical contact in connection with Biblical healings (probably in subsequent practice too) was so persistent that the faithful felt deprived when contact was denied them by interment. This sense of deprivation might well have contributed to a demand for bodies (or body-parts) with which direct physical contact was possible.

13. Mark $5^{25-34}$ and $6^{56}$.

14. Acts $19^{11-12}$. $C f$ what is said of Polycarp who, going to his martyrdom, could not loosen his shoes because each of the faithful pressed in upon him to have contact with his body, Eusebius, $H E$ 4.15.30.

15. Acts $5^{15}$. 


\section{REMAINS FROM ATTEMPTS TO DESTROY MARTYRS' CORPSES}

Demand, however, was not the only possible reason for the development of relic-devotion; there was also supply. Here the Roman authorities seem to have obliged by making it their practice at an early date to destroy the corpses of those whom they had put to death for refusing to sacrifice to the gods; ${ }^{16}$ there is not much doubt why. Eusebius reports an instance in which some imperial servants who had died as Christian martyrs and then been decently buried were subsequently disinterred by their masters and cast into the sea: this (he says) was done to ensure that no-one would worship them as they lay in their sepulchres i.e. decently buried. ${ }^{17}$ This may explain why we hear so often of martyrs, dead or alive (usually more dead than alive to judge from something Eusebius says) being fed to wild beasts. Listing the atrocious sufferings of the martyrs Eusebius says they underwent "all kinds of punishment and torture and finally were given to be eaten by the wild beasts". But after Ignatius of Antioch was thrown to the wild beasts $c a$ $107 A D$, "Only the tougher parts of his relics were left and these were carried back to Antioch and laid in a sarcophagus, being left to that church a priceless treasure of the divine grace manifested in the martyr". ${ }^{18}$ Thus it is not impossible that among the first physical relics to be cherished un-inhumed were bones from which wild animals had chewed all the flesh, but there were other types of remains. Thus, when Polycarp of Smyrna was martyred on 23 February 167 or 177 , the centurion in charge of the execution immediately burnt the body "as was their custom" (hôs ethos autois). This however failed to achieve the desired end of preventing veneration of the remains. One of those who witnessed the execution wrote:

16. The burning of a body is a grave indignity and an insult in the Hebrew tradition: Amos 2.1, Joshua $7^{25}$. In Roman law the bodies of executed criminals are to be handed over to those who request them: such is the opinion of Paul the Jurist and Ulpian (2nd cent. AD): Digest I.XLVIII, tit. XXIV, leges 3 \& 1.

17. Eusebius, $H E$ 8.6.7.

18. Eusebius, HE 4.15.4 and Martyrdom of Saint Ignatius, The Antiochene Acts (of doubtful authenticity) c.7, The Apostolic Fathers edited and translated by Joseph Barber Lightfoot, 2nd. edition, 2 vols., 1889-1890, 2:492 and 578. 
... we later took up the bones, more valuable than precious stones, of more esteem than gold, and placed them in a fitting location. There, insofar as it is possible to do so, we shall meet together in joy and gladness (when the Lord permits) to celebrate the anniversary-day of the martyrdom: this in memory of those who suffered before us and for the preparation and training of those who are going to suffer. ${ }^{19}$

Now, there being no obligation to inter the burnt remains (since the corpse had already been subject to one of the four acceptable ways of disposing of corpses) these could be legitimately kept above ground, visible and accessible. There is no doubt that this is what happened at least in one case, for the cult of martyrs' ashes is well documented by the famous passage in which. Jerome condemns Vigilantius for asking: "Why do you kiss and adore a bit of powder wrapped up in a cloth?" and alleging that "everywhere a paltry bit of powder, wrapped up in a costly cloth, is kissed and worshiped". ${ }^{20}$

The reasons for this devotion to the ashes were no doubt multiple but featuring largely among them was a conviction that if the healing dynamis of a truly holy person were so powerful in life that it could be channelled elsewhere (e.g.) by means of "aprons and handkerchiefs", it must also be sufficiently powerful to survive death and still be present in his/her mortal remains (just as radio-activity can survive almost any treatment). Undoubtedly the ashes sometimes did perform what they were believed to be capable of doing: they really did produce the healing effects the holy person had produced in life. Among the ashes there would be bones or parts of bones and these too would have been taken up whenever possible, placed in suitable receptacles and sometimes no doubt deposited in inaccessible places. But it seems by no means unlikely that these were also on occasion put into circulation, the way the bags of ashes which so troubled Vigilantius were obviously circulating; this too could be one of the ways in which the use of human remains crept into Christian

19. Eusebius, $H E$ 4.15.43-44. For bibliography and the impact of this execution on public opinion, see Doron Mendels, The media revolution of early Christianity, Grand Rapids 1999, pp. 59-60.

20. Jerome, Contra Vigilantium tr W.H. Freemantle, Select Library of Nicene and Post-Nicene Fathers 6:417-423, Patrologia Latina 23:353-368, c.4 (357B); $c f$ Rufinus on the ashes of John the Baptist after Julian had the bones burnt, $H E$ 2.28, PL 21:536AB. 
devotional practices. And here there was no legal impediment, for ashes and calcified bones, as we just said, are not cadavers. But the vast majority of the primary relics beloved of our forefathers (and mothers) were neither ashes nor calcified bones: they were dead human flesh and bone; parts of a cadaver, a thing which has neither been laid in earth, consumed by fire, buried at sea nor exposed to the birds of the air. It is an unfinished task: it is also, frankly, a health risk, which is why most people held it at arm's length, if not in horror. Why then did Christians suffer human remains to be "reserved, carried about, lifted up or worshipped". ${ }^{21}$

\section{HebreW AND GREEK EXCEPTIONS TO GENERAL PRACTICE}

Let us pause and observe before going further that the abhorrence of cadavers was not quite as unequivocal as may have been suggested thus far. Even in the Hebrew tradition there was provision for the disturbance of a grave in exceptional circumstances:

To disturb the rest of the dead by removing the body or the boneremnants from one place to another was considered a great wrong; but it was allowed for the benefit of the dead in the case of the transfer of the body to the family plot, or when the place of burial had become unsafe from desecration or elementary ruin. ${ }^{22}$

And even though tombs were technically a source of ritual pollution [Lev.21, 1-4; Num 19, 11-16] some tombs were nevertheless venerated by the Jews, mainly in Judaea. Joachim Jeremias has identified forty-nine such tombs containing: eight patriarchs, twentyone leading figures in Hebrew history, nineteen prophets (two of whom may have been martyrs) and one whose sole claim to fame was martyrdom. ${ }^{23}$ Every one of these was the object of a degree of veneration. Yet in every one of these cases the tombs were sealed, the relics inaccessible.

21. Thus the 28th of the Thirty-Nine Articles of 1562, referring to the eucharistic species.

22. Karl Kohler, "Burial", The Jewish Encyclopedia vol. 3 (New York, 1916) p. 437 with references (italics added).

23. James Bentley, Restless bones: the story of relics (London, 1985) p. 36. 
Nor did the Ancient Greeks' insistence on burial altogether exclude a relics-cult which, in their case, was ancillary to the cult, not of saints, but of heroes. ${ }^{24}$ As Plato said they should be, the mortal remains (sometimes the ashes) of great heroes were often preserved in temples located in the main squares of their cities, e.g. the bones of Theseus at Athens, of Orestes at Sparta, of Tantalus at Argos; the shoulder-blade of Pelops was preserved at Elis, the head of Orpheus at Lesbos (these last two larger than life). ${ }^{25}$

Ces reliques avaient les pouvoirs les plus divers. Elles guérissaient les malades, rendaient les terres fertiles, éloignaient la peste et la famine, assuraient la protection des villes et des états, donnaient la victoire à leurs armées. Aussi en temps de péril cherchait-on passionément à en acquérir. Des oracles, des prodiges permettaient de les découvrir. Si les reliques convoitées étaient déjà honorées dans une autre cité, on n'hésitait pas à recourir à la force ou à la fraude pour les subtiliser. Si d'une manière ou d'une autre on parvenait à se procurer de précieuses reliques, elles étaient portées solennellement dans la cité; un monument était érigé sur le lieu où elles avaient été déposées et une fête était célébrée chaque année en leur honneur. ${ }^{26}$

One might well imagine this to be a description of circumstances in the Christian Middle Ages, for it fits at all points. But the writer is speaking of Ancient Greece, and of the relics of pagan heroes, not of Christian saints. This striking demonstration of the extent to which the cult of relics already existed in antiquity enjoins great caution when exploring the origins of Christian usage; but for all the similarities, except when a relic was being "translated", so far as one can tell, it was always hidden from sight among the Hellenes, never available for touch.

24. See (most recently) R. Albrecht and W. Ameling, "Reliquien", Der Neue Pauly vol. 10, Stuttgart 2001, pp. 918-919 with bibliography.

25. Nicole Hermann-Mascard, Les reliques des saints: formation coutumière d'un droit. Paris 1975, pp 13-14. There was also a plentiful supply of what would later be called "secondary relics" such as a hero's weapons, his musical instruments (Orpheus' lyre), Agamemnon's sceptre, Helen's sandals, a hero's throne, his jewellry; even the very ship which brought Æneas to Rome.

26. Ibid., p. 15. Mme Hermann-Mascard notes a little later (p. 23) that the pagans would go to the tomb of a hero bearing flowers and incense, to celebrate a banquet there on his birthday, genethlion. The resemblance to later Christian practice at martyrs' tombs is most striking. She believes that the use of relics is a universal human phenomenon. 


\section{Athanasius' condemnation of the Egyptians' PRACTICE}

There was however in the ancient world one people whose attitudes to corpses and death were very different from most others': the Egyptians. Since time immemorial it was their practice to preserve the bodies of the departed by embalming, thus transforming them into mummies. In the process of time, as Greek and then Roman ideas filtered into Egypt, changes came about in the traditional procedure. One of the best known examples is the practice of painting the face of the departed on the mummy (the famous Fayum portraits are the notable examples) ${ }^{27}$ - the sort of youthful, rejuvenated face that is, with which one would wish to enter eternity. By a curious paradox the Egyptians were inspired in their funerary practices by a belief which would be shared by the Christians in due course: a belief in life after death. This may explain why, when Christianity came to the Nile Valley, the Egyptians appear to have taken to it with alacrity. Inevitably, they also set their own very distinctive stamp upon Christianity, a stamp which owed much to the religion and beliefs of their ancient ancestors, which had itself been subject to transformation over the centuries.

The old Egyptian tradition was that the bodies of the dead, once they were mummified, were to be inhumed or placed in sealed sepulchres ${ }^{28}$ surrounded by the things they might need in the afterlife. This tradition, however, had been modified with the process of time, as we learn from Athanasius, Pope of Alexandria. Writing in the 360s he says this of Anthony the Great, the so-called "first monk", believed to have died in 356 in his one hundred and sixth year:

The brethren were trying to persuade Anthony to stay with them until he died, but he refused for several reasons, which he indicated whilst still keeping silent, and for this reason above all. It is the custom of the Egyptians to perform the funeral rites for the corpses of men of

27. See (most recently) Euphrosynê Doxiadis, The Mysterious Fayum Portraits: faces from ancient Egypt, London and New York 1995.

28. "In editoribus cellulis reconduntur" says John Cassian of his departed Egyptian confrères, i.e. each in his own sepulchre, like the virgins in The Lausiac History c. 33, eis ta idia mnêmata, edited by Cuthbert Butler 2:96 line 13. 
distinction, especially for the corpses of the holy martyrs, and to wrap them up in linen, not to conceal them below ground, but to lay them on low beds [epi skimpodion] and to keep them at home, within doors. In this way they thought they were honouring the departed. Many a bishop did Anthony ask to preach about this to the people; he cried shame on the laity and chastised the women, saying the practice was illegal and unholy, for the bodies of the patriarchs and prophets remain within their tombs to this day; and even the body of the Lord was placed in a sepulchre and a stone set in place to conceal it until he rose again three days later. In these words [Anthony] demonstrated the perversity of not putting away the bodies of the deceased after death, no matter how holy the corpses might be, for what could be greater or more holy than the body of the Lord? So, many who heard finally concealed [their deceased] beneath the ground; and they gave thanks to the Lord for having been so well instructed. ${ }^{29}$

(Let it here be added that, according to Jerome writing ca 390, when Hilarion visited the site of Antony's askêsis shortly after he died, "the elder also asked to be shown the place of [Antony's] tomb, whereupon they took him aside". But it is not known whether they showed it to him or not, claiming that the reason for concealing its whereabouts was Antony's directive; this was to ensure that Pergamius, an extremely wealthy person in those parts, should not remove the body of the saint to his villa and construct a martyrion.) ${ }^{30}$

It is of course somewhat unlikely that Anthony signalled anything of the sort. It is far more likely that Athanasius saw this as an excellent opportunity to take issue with a practice which he found distasteful, unchristian and maybe even dangerous. It is not the mummification of the distinguished dead to which he takes primary exception, but the retention of the mummified remains on display, at home - when

29. Athanasius, Vita Antonii (BHG 140), c. 90 (our translation), edited and translated by G.J.M. Bartelink, Athanase d'Alexandrie, Vie d'Antoine, SC 400, Paris 1994, pp 364-367.

30. Jerome, Life of Hilarion the Hermit c.31, PL 23:47A. (praeterea rogabat senex [sc. Hilarion] ut sibi locum tumuli eius [sc. Antonii] ostenderent. qui cum seorsum eum abduxissent utrum monstraverint necne ignoratur, causam ocultandi iuxta praeceptum Antonii fuisse referentes, ne Pergamius, qui in illis locis ditissimus erat, sublato ad villam suam sancti corpore, martyrium fabricaretur.) Nevertheless, there are accounts of an invention of the relics of Antony in the reign of Justinian (I or II?) and of their translation to Alexandria, with a further translation to Constantinople in 670: Acta Sanctorum ianuarii. ii:513ff. 
(in his opinion) these ought to be entombed or inhumed. Others who have studied this remarkable passage ${ }^{31}$ are agreed that the original practice, once the embalming process was complete, was indeed for the mummies either to be sealed in sepulchres "standing up against the wall" 32 pace Herodotus or to be buried below ground (presumably lying down).

\section{History OF THE EgYPTIAN PRACTICE}

As Theofried Baumeister noted some time ago, there is evidence that concealment of the mummy had ceased to be the universal practice long before Athanasius protested. Teles, the cynic teacher probably from Megara who flourished $c a 235$ BC says: "We [Hellenes] hesitate to look at or touch [the dead] but they [the Egyptians] mummify and keep them in the house as something good and accept the bodies as sureties, so opposed is their way to ours." 33 Cicero says quite bluntly (and alas without comment, maybe quoting Chrysippius): "The Egyptians embalm their dead and keep them in

31. Alfred C. Rush, Death and Burial in Christian Antiquity, Washington DC 1941, 2.4.1, "Pagan cremation and Christian interment", pp. 236ff.; Theofried Baumeister, "Vorchristiliche Bestattungssitten und die Entstehung des Märtyrerkultes in Ägypten" [Pre-Christian burial customs and the rise of the cult of martyrs in Egypt], Römische Quartalschrift 69 (1974) 1-6. See also the article of D. Hall in Hasting's Encyclopaedia of Religion and Ethics 4:458-459.

32. Herodotus $2.85 \mathrm{ff}$.

33. Teles (the cynic teacher) translated by Edward N O'Neil, Missoula Mont. 1977 pp. 32 190-193 and 33. As O'Neil comments (note 49) there is a lacuna immediately preceding this passage; hence it is not stated who "they" are, but taking into consideration something Herodotus says (2.136.2) there is not much doubt: "They said that when Asuchis was king in Egypt, because money passed not easily from hand to hand, a law was made that a man might borrow on the security of his father's dead body; and the law provided also that the lender should have a lien on the whole burial vault of the borrower, and that the penalty for the giver of this security should he fail to repay the debt, should be that he might neither himself be buried at death nor bury any deceased of his kin either in that tomb of his fathers or in any other", translated by A.D. Godley, Loeb 1920, pp. 440-441. Might one surmise that mummies first came out of tombs when creditors foreclosed on them? 
their houses." 34 This is confirmed two centuries later by Sextus Empiricus: "Some wrap their dead up completely then cover them with earth, thinking it is impious to expose them to the sun. But the Egyptians take out their entrails and embalm them and keep them above ground with themselves [or "at home", syn heautois]. ${ }^{35}$ Writing maybe half a century earlier than that ( $c a 150 A D)$ Lucian of Samosata is even more explicit:

The Greek burns [the dead], the Persian buries, the Indian encases in glass, ${ }^{36}$ the Scythian eats, the Egyptian salts. And the latter -- I have seen whereof I speak -- after drying the dead man, makes him a guest at table. Many a time too when an Egyptian wants money his [mummified] brother or his father helps him out of his straits by becoming security at the critical juncture. ${ }^{37}$

It appears that a mummy was of sufficient intrinsic worth to be counted an asset. This is hardly surprising given the long-drawn-out process of preparation described by Diodorus Siculus which, already in his day (first century BC) terminated with careful painting so that "the entire appearance of the body is unchanged". He continues:

This explains why most of the Egyptians [actually, "many"] keep the bodies of their ancestors in valuable chambers [en oikêmasi polytelesi] and gaze face to face upon those who died many generations before their own birth so that, as they look upon the stature and proportion and features of the countenance of each they experience a strange enjoyment as though they had lived with those on whom they gaze. ${ }^{38}$

From this passage it may be possible to catch a glimpse of what happened. As the undertakers' skills improved, the resulting mummy came more and more to resemble the departed person (as can well be seen in the exquisite Fayum portraits), thus provoking an everincreasing reluctance to stow the likeness where it could no longer be seen. Most people are motivated by a desire to look upon those

34. Cicero, Tusculan Disputations 1.45, translator. Anon., Princeton NJ 1852.

35. Sextus Empiricus, Outlines of Pyrrhonism 3.226 translated by R.G. Bury, Loeb 1933.

36. Herodotus (3.24) mentions this too; it is something of a mystery to the commentators.

37. Lucian of Samosata, On funerals / De luctu 3.170, translated by A.M. Harmon, Loeb 1925.

38. Diodorus Siculus 1.91.6-7, translated by C.H. Oldfather, Loeb 1933. 
they loved, also indeed upon those whom they loved and so forth, hence the whilom popularity of the family photograph album (or of the death-mask in its time). From there it was a short step to setting the mummy, not in an hermetically sealed chamber, but in "a costly chamber" (presumably part of the home) to which access could be gained on occasion. Once that concession was made, the pressure to release the mummy from the home would be eased -- and the way be open for it to remain there for some time; in practice, for it to remain at home (syn heautois) more or less in perpetuity.

Thus the practice to which Athanasius addressed himself was not by any means a new one; local law either allowed it (which Roman Law certainly would not have done) or looked the other way. This is hardly surprising because, of course, when Diodorus Siculus says that most, or even many, Egyptians indulge in this practice he is clearly exaggerating. It was an indulgence only of the very wealthy to have their loved ones transformed into valuable assets that could be used as collateral and to stow these in costly chambers. ${ }^{39}$ And Athanasius says: "It is the custom of the Egyptians to perform the funeral rites for the corpses of men of distinction", probably meaning the sort of people for whom a statue would have been erected in the nineteenth century. But Christians have not been remiss in taking up the challenge; now (he says) they do this "especially for the corpses of the holy martyrs". It is worth reflecting that by the time Antony died, and a fortiori by the time Athanasius wrote about him, the age of persecutions was several decades in the past, hence their mummified remains must have been around for quite some time. Also that with the end of persecutions, the supply of martyrs' remains had dried up, while the demand for them appears to have increased; increased, it would appear, to the point where the remains of a distinguished holy man would be acceptable as an alternative to martyrs' relics.

39. Baumeister (art. cit.) makes the interesting suggestion that the exhibiting of the mummy may have been a display of wealth. 


\section{Reasons for Athanasius' opposition to the Egyptian Practice}

Why, one might well ask, was Athanasius so bitterly opposed to the practice of keeping the mummies of the distinguished dead in homes? One possibility is that he wanted to preclude the emergence of martyria in his territory over which he had no control. In this context it may be significant that it is specifically the laity, men and women, whom he reproves, not the clergy. He was himself, after all, in possession of one of the two mêlôtai (sheepskin cloaks) of Antony and maybe hoped to make that the focal point of a cult. ${ }^{40}$ It is also possible that, given his intensely humane Christology, Athanasius was disturbed by a practice which prevented human remains from returning "dust to dust, ashes to ashes". ${ }^{41}$ But a much more likely explanation is that he knew that the practice opened the way for what in his eyes were the very serious crimes of dismembering corpses and trafficking in them, two essential concomitants of the veneration of accessible relics. This we know from one of the Festal letters to which Baumeister has drawn attention. ${ }^{42}$ In it Athanasius points an accusing finger quite deliberately at a particular group of people, the schismatics we know as the Melitians, whose "wicked and evil intent", also "their ancient evil and apostasy", are noted in The Life of Antony. ${ }^{43}$

The Melitian schism was named after Melitius of Lycopolis who, shocked to find Bishop Peter of Alexandria had gone into hiding

40. Mêlotê is the word in the Septuagint for the mantle of Elijah which fell upon Elisha and with which both divided Jordan: a significant secondary relic (of which we never hear again): 3 Kings 1913,19; 4 Kings 28,13,14. Also called to trichinon endyma, Vie d'Antoine 47.2, 91.9.

41. A remark of Calvin is apposite here: 'C'est l'office des chrétiens de laisser les corps des saints en leur sépulchre, pour obéir à cette sentence universelle que tout homme est poudre et retournera en poudre, non pas de les élever en pompe et somptuosité pour faire une résurrection devant le temps. Cela n'a pas été entendu, mais au contraire, contre l'ordinance de Dieu, on a déterré les corps des fidèles pour les magnifier en gloire, au lieu qu'ils devraient être dans leur couche et lieu de repos, en attendant le dernier jour," Jean Calvin, Traité des Reliques, ed. Albert Autin, Paris 1921, pp. 92-93.

42. Art. cit., note 31.

43. Vie d'Antoine 68.1 and 85.4. 
during the recent wave of persecution, established a rival episcopate at Alexandria and in the Thebaid $c a 306$, thus provoking a schism which lasted into the eighth century. It need not have lasted; at the Council of Nicaea in 325 generous terms were worked out for the reconciliation of the Melitians (whose convictions were remarkably similar to those of the Donatists in North Africa $)^{44}$ but the arrangements collapsed, partly because Melitius created a successor (John Arkaph, bishop of Memphis) shortly before he died ( $c$ a 328); but mainly because, according to Epiphanius of Salamis, when Athanasius acceded to the bishopric of Alexandria in 328, he "rekindled his anger at the schism in the church and saw fit to offer every kind of harassment and hindrance to those who assembled by themselves and whom Melitius had left behind and forcibly to prevent them from rebelling against the church". ${ }^{45}$

Predictably, this attitude provoked the bitter hostility of the schismatics. ${ }^{46}$ They presented their case to Eusebius of Nicomedia, newly returned from exile for championing the Arian cause. A bitter enemy of Athanasius, Eusebius (bishop of the then imperial city of Nicomedia) welcomed the complaints of the Melitians, cooperated with them and thus succeeded in securing the first exile of Athanasius at the Council of Tyre in 335, while Eusebius himself went on to occupy the see of Constantinople in 339 but died in 342. Although the Melitians were not themselves Arians, by throwing in their lot with Eusebius of Nicomedia for political reasons, they added insult to the injury of schism within Athanasius' ecclesiastical jurisdiction. In his mind the heresy which he would make it his life's work to extirpate was now identified with his most bitter enemy. Hence it is scarcely surprising that there is no shortage of evidence that the antipathy of the Melitians to Athanasius was hotly reciprocated;

44. Epiphanius of Salamis insists that "[Meletius'] faith never changed from that of the holy catholic church", Panarion 68, tr. Frank Williams, 2 vols. Leiden \&c 1987 \&1994, 2:315

45. Panarion 68, tr. Williams 2:319.

46. "Désormais les melitiens vont se montrer les adversaires acharnés du jeune archevêque", E. Amann, "Mélèce de Lycopolis", DThC 10 (i/1928) 531-536. 
witness especially his Apology against the Arians. He accuses them of nearly every misdemeanour imaginable, and often too.

The accusation which particularly concerns us here is only known to have been hurled at them once; it is found in a Festal Letter the text of which has only survived in Coptic and in a lacunous condition but it speaks clearly enough. There is a hint of what is to come when the Pope of Alexandria says that, in common with Pilate and Herod, the Melitians "dare to oppose the Saviour and to insult the saints who have fallen asleep in His name". ${ }^{47}$ Then he charges explicitly:

They do not keep the bodies of the martyrs (who have nobly striven) hidden in the earth but put themselves to the trouble of placing them on biers and trestles so that anybody who wishes to may look upon them. This they do theoretically to honour them but in fact they insult them; and they do it for a despicable reason. As they have no martyr's body in their town and do not know what a martyr is, they have come up with the idea of stealing martyrs' bodies and of taking them up from the cemeteries of catholic churches. In fact, while we charge them with denying Him whom the martyrs confessed, they beg the bodies from those who have just buried them; they transfer them from one place to another to find a way of deceiving those whom they are leading astray, even with their bodies [...] Our fathers did not bequeath that to us; on the contrary, they think that such a practice is illicit. ${ }^{48}$

This all seems to be congruent with what he says in the Life of Anthony, but there is a greater wrong involved here than merely exposing the bodies of the martyrs:

Who can despise the heretics as much as they deserve? Who would not just like to run into them when they are insulting the bodies of the saints like false prophets? Who could endure unmoved the spectacle of the bodies of prophets and the bodies of martyrs thrown up and exhibited? This is not Christian behaviour; Paul did not bequeath this to us; neither patriarchs nor prophets did this in the course of the ages. But it

47. S. Athanase, Lettres Festales et Pastorales en Copte edited and translated by L.-Th. Lefort, Corpus Scriptorum Chistianorum Orientalium 151, Scriptores Coptici vol.20, Louvain 1955, Lettre XLI pp. 41-45; pp. 4210-4212 (our translation of Lefort's French). See also Alberto Camplani, Atanasio di Alessandria, Lettere Festali \& c, Milan 2003 for a new and annotated translation in which he dates Letter 41 to Easter 369 A.D.

48. Lefort p. $41^{13-27}$, and a little later: "It is a blatant misfortune to play the beggar and the marauder at the martyrs' tombs and not to bury them like the saints and, above all, like the Lord", p. 4324-27. 
is the Melitians who have turned in this direction, to profit from it. It is being shrewd like Jeroboam who sold doves and changed money in the temple, as the Scripture says. [Jer 22 18-19] There are no two ways about it: to those who were in error at that time and were driven out by whipping the Saviour said: "Do not make of my Father's house a tradinghouse" [Jo 2 16] These [Melitians] will doubtless hear Him saying to them: "Do not sell the bodies of my martyrs and do not make their fine confession a commodity to be traded, for the love of money", for they who commit such a villainy will doubtless receive a commensurate punishment. ${ }^{49}$

Thus the Melitians are accused not only of exhibiting martyrs' corpses, but also of trading in them for filthy lucre. How seriously can these accusations be taken? There is no denying that Athanasius was extremely angry with the Melitians whose very existence depreciated his claim to the primacy of Egypt: and angry men sometimes make excessive allegations. ${ }^{50} \mathrm{He}$ wanted to say the worst of them that could be said, and this was probably it. Nowhere else (so far as we know) are these charges made. But that they were ever made at all clearly indicates that the practices spoken of were known to occur. Athanasius may well have feared (and that with all too real justification) that maintaining martyrs' remains in secular dwellings was tantamount to inviting abuses of the kind mentioned above; abuse not only of any genuine remains, but also of persons who longed to possess such remains but had not been fortunate enough to acquire them legitimately.

From the condemnation with which Athanasius credits Antony it is perfectly clear that the pagan practice of preserving the distinguished dead in homes had already spread to the Christians (who may well simply have brought it with them when they were converted). From his diatribe against the Melitians we perceive that he was well aware of the danger which lay in this practice for Christians (but which probably did not threaten pagans): the danger of wicked

49. Ibid. p.44-20.

50. The Melitian schism certainly did not come to a sudden end; Theodoret of Cyrr (who died ca 466) writes: "Even to this present day there do remain remnants of his [Melitius'] mad opinion and there are in those places certain companies of monks whose doctrine is not sound, following in their order and conservation of life many foolish and vain observations and addicting themselves wholly to the frantic madness of Jews and Samaritans Theodoret, HE 1.9 (end) anonymous translator, A.D. 1612, PG 82:932BC. 
men profiting from the demand for relics, probably by dismembering mummies and disseminating the parts (each of which, we recall, was held to emanate the healing dynamis of the entire corpse.) Although in The Life of Antony Athanasius does not spell out the danger of exhibiting martyrs' mummies in homes he does nevertheless focus his attack on the root problem. Like Tertullian claiming that if there were no idol-makers there could be no idolatry, ${ }^{51}$ Athanasius advocates the speedy, indeed the immediate, inhumation of corpses (preferably in places known only to a select few) because in this way there can be no more trafficking. Speaking through the mouth of Anthony, he seems to be saying to those who will hear him: "Maybe your pagan neighbours keep the corpses of their distinguished compatriots exposed in their homes on biers (epi skimpodiôn); but you, Christians, must cease and desist forthwith" (sous-entendu: thus there will be no more trafficking in relics).

\section{CONCLUSION}

There is of course absolutely no indication that the Christians of Egypt did anything such thing; bishops are rarely obeyed when they talk like that, even when they borrow the voice of a holy man to do so. And, in this case, it is easy to see why. By keeping the embalmed body of a martyr at home, epi skimpodion, not only was the home itself transformed into a private martyrion; it also became a martyrion in which the holy relic, far from being entombed, was openly visible and tangible: in other words, accessible to physical contact. Now if healings could be produced by the ashes and/or bones (bloodied or calcified) of a martyr how much more so might healings be expected when the very body itself was present and could be physically handled? A body, moreover, which, thanks to the undertakers' skills, might very closely have resembled the saint in life, and thus have been in a certain sense both relic and icon?

51. "Caput facta est idolatriae ars omnis quae idolum quoquomodo edit", Tertullian, De idolatria edited and translated by J.H. Waszink and J.M.C. Van Vinden, Leiden \&c 1987, 3.2. 
Maybe we can go even a little further; if healings began to occur where a martyr's mummy lay epi skimpodion, given the demand for relics, would not the temptation have been enormous to steal away with, first little fragments of the winding-cloths (so like "handkerchiefs and aprons"), some dust from beneath the skimpodion, then small and even larger portions of the mummy itself (each in its way to become the focal point of devotion elsewhere) until the poor corpse was reduced to a mere shadow of its former self? In a eulogy of Saint Theodore Tiro composed about 380 by Gregory of Nyssa says:

Having delighted his eyes with the visible artistry of the shrine [the worshipper] desires to approach the casket [thêkê] itself, believing that to touch it is a sanctification and a blessing. And somebody is granted the privilege of taking dust from the presence of the resting-place, he receives that earth as a gift and as soil which is to be treasured as a thing of great worth [keimêlion]. Actually to touch the relic, should good fortune grant such a privilege, those who have experienced it and have realised the desire to do it know highly desirable a thing it is and the answer to most fervent prayer. Those who behold [the relic] embrace it as though it were a live and flourishing body, kissing the eyes, the mouth, the ears and all the senses. Then, shedding tears of devotion and sorrow, they present their requests for [the martyr's] intercession as if they were presenting them to the whole and visible martyr; as though they were calling upon the minister [doryphhoros] of God and imprecating one who received free gifts at will. ${ }^{52}$

Athanasius may well have been all too aware of such practices and tendencies, but there was probably very little he could do about it. All the indications suggest that matters were out of hand by his time; i.e. that the cult of relics and fragments of relics of martyrs (and eventually of holy men, even of bishops) was already making its way through Palestine-Syria and on into the rest of the Empire. ${ }^{53}$

52. De Sancto Theodoro martyre, $P G$ 46:740AB.

53. Two major land-marks in this process are: the translation of the relics of the Apostles Andrew, Timothy and Luke to Constantinople (where they were inhumed) with the sanction of the Emperor quâ pontifex maximus in 359 and the celebrated constitution Humatum corpus of Theodosius I AD 386: "No person shall transfer a body to another place. No person shall sell the relic of a martyr; no person shall traffic in them. But if any of the saints has been buried in any place whatsoever, persons shall have it in their power to add whatever building they wish in veneration of the saint [or the place] and such building is to be called a martyrion", Codex Theodosianum 9.17.6 AD 386, translated by Clyde Pharr, The Theodosian Code, Princeton 1952, p. 240. 
It is surely no mere coincidence that "the martyrs of Egypt" figure so prominently in the earliest stratum of relic-literature, after which the Holy Land and Antioch become the chief relic-suppliers. The Egyptians had made respectable that which Roman Law forbade: the transportation and maintenance above ground of human remains.

If this was indeed one of the ways in which the cult of uninhumed body-parts arose it is worth noting in conclusion that this is not by any means the only element of early Christianity which owes more to Egypt than to either Israel, Greece or Rome. Christian monasticism, for instance, which, like Melchizedek, has no perceptible progenitors, ${ }^{54}$ arose in Egypt. It was within Egyptian monachism that the tradition of "spiritually beneficial tales" developed. It is becoming increasingly clear (as Wallis Budge suggested a century ago $)^{55}$ that the roots of this tradition lie deep down in ancient Egyptian folklore. One can go further: within the tales-tradition, the notion of the psychomachia, (the contention of the powers of darkness and light for the soul of a dying person) is almost certainly derived from the religion of Isis and Osiris. It may also well be that the earliest painted Christian icons made their first appearance in Egypt, probably inspired by the practice of portrait painting on mummies.

Thus at least one of the answers to the question of why the Christians embraced the physical remainsof the blessed may well be that the Christians of Egypt (probably of Alexandria in particular) "as members of the Hellenised population that had largely adopted the Egyptian way of death" 56 conflated "the Egyptian way of death" with the NT teaching of the way the dynamis of the holy could be

\section{Hebrews. $7^{3}$.}

55. Wallis Budge opined that Christians of Coptic expression used their Egyptian religious traditions to fill out the vacuums in their Judaeo-Christian beliefs and he provided at least one striking example of them appropriating Egyptian notions of what they (wrongly) supposed to be hell: E.A. Wallis Budge, Egyptian ideas of the future life, London 1899 pp. 110-115, also ibid., The Book of the Dead, 1910, reprint New York 1960, pp. 313, 318 et passim.

56. As Euphrosynê Doxiadis neatly puts it, op. cit. p.89. "The Egyptian veneration of the martyrs confirms the view that from its beginnings the cult of martyrs was an enhanced commemoration of the dead taken from everyday life", Theofried Baumeister, art. cit., conclusion. 
disseminated and that this was how Christendom learnt to revere the uninterred relics of the holy dead.

\section{AdDitional nOTE}

The bodies of holy men were not even safe from their fellow ascetics, let alone laity, in the later fourth century. According to Jerome writing ca 390, the dying Hilarion, echoing the aged Antony, "earnestly entreated them all not to let him be kept even a moment of time after death, but to bury him immediately in the same garden, just as he was, clad in his goat-hair tunic, cowl, and his peasant's cloak" (Life of Hilarion c.44); "He was immediately buried before the city heard of his death" ( $c$ a 370; c.45). But "When the holy man Hesychius [his lifetime companion] heard of his decease, he went to Cyprus and, to lull the suspicions of the natives who were keeping strict guard, pretended that he wished to live in the same garden, and then in the course of about ten months, though at great peril to his life, stole the saint's body. He carried it to Majuma; and there all the monks and crowds of townsfolk going in procession laid it to rest in the ancient monastery. His tunic, cowl and cloak, were uninjured; the whole body as perfect as if alive, and so fragrant with sweet odours that one might suppose it to have been embalmed" (c.46).

wortley@cc.umanitoba.ca 